\title{
Atmospheric Boundary Layer Simulation Using Wall Function Approach in OpenFoam CFD Software
}

\author{
Okafor C. Vincent, Ogunoh E. Peter, Ezeokonkwo U. John and Obodoh D. Anosike
}

\begin{abstract}
The significant development in computer resources in the past years has increased the awareness of computational fluid dynamics as an alternative tool to the costly wind tunnel testing. The paper presented the application of CFD technique for a case study in simulating an existing site together with a proposed building and the local landscape. Finally, the limitations of the code analytical methods to the CFD method for wind around building analysis were discussed. From the result obtained, it was observed that the British standard (BS6399-2:1997) procedures are based on general assumptions and are not always conservative and do not provide accurate wind load results due to complex geometrical shapes, aerodynamic interaction, torsion, and load combinations as discussed in section VII.
\end{abstract}

Index Terms-Computational Fluid Dynamics; BS63992:1997; Wall function.

\section{INTRODUCTION}

Computational fluid dynamics (CFD) has widely been used to study wind phenomenon at the lower part of the atmospheric boundary layer (ABL) (0-200M). Recently, comprehensive literature reviews on the use of CFD for this application have been published in [1]-[3].

These literatures contain best practice guidelines on how CFD should be used in order to avoid or at least reduce user error. According to [4], within the computational domain, three different regions can be distinguished as illustrated in Fig. 1.

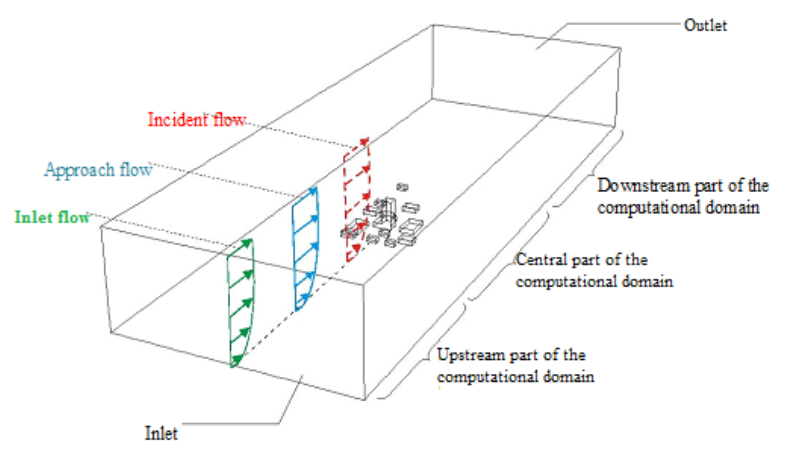

Fig. 1. Computational domain for CFD simulation of ABL flow indicating different part of the domain for roughness modelling. Modified from [4]

Published on February 6, 2018.

C. V. Okafor, Ms.c Department of Building, Nnamdi Azikiwe University Nigeria (e-mail: chinedumokafor117@yahoo.com).

P. E. Ogunoh, PhD., Department of Building, Nnamdi Azikiwe University Nigeria (e-mail: peogunoh@yahoo.com).

J. U. Ezeokonkwo, Department of Building, Nnamdi Azikiwe University Nigeria (e-mail: ezeokonkwojohn@yahoo.com).

D. A. Obodoh, Department of Building, Nnamdi Azikiwe University Nigeria (e-mail: dominicanosike@yahoo.com).
1) The central region of the domain where the actual obstacles are modelled.

2) The upstream and downstream regions in the domain where the actual obstacles are modelled explicitly i.e. their geometry is not included in the domain but their effects on the flow can be modelled in terms of roughness e.g. by means of wall functions applied at the bottom of the domain.

In CFD, wall functions are empirical equations used to satisfy the physics of the flow in the near wall region and first cell centre needs to be placed in the logarithmic law region to ensure the accuracy of the result.

A wall function replaces the actual roughness obstacles but they should have the same overall effect on the flow as these obstacles modeled explicitly [4]. Their roughness is expressed in terms of the equivalent sand-grain roughness height for the atmospheric boundary layer $\left(K_{S_{A B L}}\right)$.

This study analyzed the wind effect on a typical high-rise building using the wall function approach in OpenFoam CFD simulation. Thereafter, compared the results of the CFD simulation with the prediction given in [5].

The study sought to achieve the aim through the following objectives:

1) Calculate the wind speed at subsequent height of the high-rise building as per logarithmic wind profile equation.

2) Calculate the magnitude of design wind pressure on the facade of the high-rise building for using [5].

3) Perform a CFD simulation to determine the flow variables for wind around the typical high-rise building.

4) Compare the results obtained from CFD Simulation to the prediction gotten from [5].

5) Discuss the limitations of the [5] to CFD analysis.

\section{BOUNDARY CONDITIONS}

\section{A. Inlet Condition for Homogeneous ABL Flow}

At the inlet boundary, for steady RANS simulation, a fully developed inlet profile of the mean velocity profile, turbulent kinetic energy and dissipation rate are obtained based on the formulae suggested by [6]. where $u^{*}$ is the friction velocity derived from a reference wind speed of $3.40 \mathrm{~m} / \mathrm{s}$ at a reference height of $10 \mathrm{~m}$ and inlet roughness of 0.3 .

$$
\begin{aligned}
& u_{z}=\frac{\mathrm{u}_{\mathrm{ABL}}^{*}}{\kappa} \operatorname{In}\left(\frac{Z+Z_{0}}{Z}\right) \\
& k_{(z)}=\frac{\mathrm{u}_{A B L}^{*^{2}}}{\sqrt{C_{\mu}}}
\end{aligned}
$$




$$
\varepsilon_{(z)}=\frac{\mathrm{u}_{A B L}^{*^{3}}}{\kappa\left(z+z_{0}\right)}
$$

\section{B. Wall Treatment}

No slip boundary type was specified for the wall velocity. The standard approach for rough surfaces in CFD simulation consist of a modification of the standard smooth law of the wall [7]:

$$
\frac{u}{u^{*}}=\frac{1}{k} \operatorname{In}\left(\epsilon \mathrm{Z}^{+}\right)-\Delta \mathrm{B}\left(\mathrm{K}_{\mathrm{s}}^{+}\right)
$$

where $Z^{+}=\frac{u^{*} z}{V}, K_{S}^{+}=\frac{u^{*} k_{S}}{V}$

$Z^{+}$is the non - dimensional distance from the wall

The function $\Delta B\left(K_{S}\right)$ depends on the dimensional roughness height $K_{S}^{+}=K_{S} \frac{u^{*}}{V}$ and measures the departure of the wall velocity from smooth conditions.

According to [8], the roughness function $\Delta B$ takes different forms depending on the $K_{S}^{+}$value.

Three regimes are distinguished:

- Aerodynamically $\operatorname{smooth}\left(K_{S}^{+}<2.25\right)$

- Transitional $\left(2.25 \leq K_{S}^{+}<90\right)$

- $\quad$ Fully rough $\left(K_{S}^{+} \geq 90\right)$

In OpenFoam and in an equilibrium boundary layer, assuming a fully rough region, equation 4 can be approximated by

$$
\frac{u_{p}}{u^{*}}=\frac{1}{k} \operatorname{In}\left(\frac{\in z_{p}^{+}}{C_{S} K_{S}^{+}}\right)
$$

where $C_{S}$ is a roughness constant which is set to ensure first matching order between the law of the wall and the inlet profile condition, $\in$ is a smooth constant.

$$
C_{S}=\frac{\in z_{0}}{K_{S}}
$$

For this analysis, $K_{S}=20 z_{0}$.

\section{Outlet Boundary}

At the downwind boundary, an outflow boundary type was used with constant static pressure and boundary condition for $k$ and $\varepsilon$ set to those of inlet. Backflow was not observed because the outlet boundary was sufficiently far away from the building.

\section{Top Boundary}

Along the length of the top boundary, the values from the inlet profile of $u, k, \varepsilon$ at this height were imposed. According to [4], the application of this particular type of top boundary condition is important because other top boundary conditions (symmetry, slip, wall, etc) can themselves cause stream wise gradient in addition to those caused by wall function.

\section{E. Lateral Boundary}

Symmetry boundary condition was imposed on the lateral boundary following recommendation by [1].

\section{Computational Domain}

The computational domain used for the study was adopted according to recommendations by [1], the inlet, the lateral and the top boundary away from the high-rise building model was $5 \mathrm{H}$ while the outflow boundary was $15 \mathrm{H}$, leading to a blockage ratio of $1.8 \%$. Where $\mathrm{H}$ represents the height of the building.

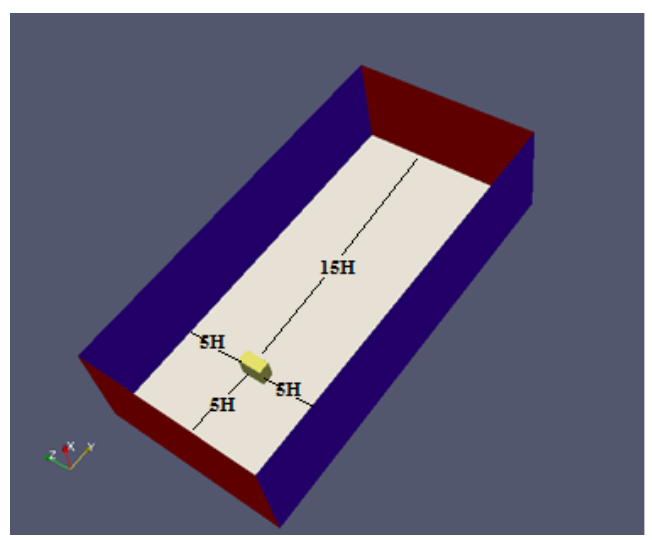

Fig. 2. Computational Domain

\section{SOLVER SETTING}

SIM-FLOW commercial CFD code was used to perform the simulation. The 3D steady RANS equation was solved. The simple algorithm was used for pressure-velocity coupling, pressure interpolation was second order and second-order discritizaton scheme was used for both the convective terms and the viscous terms of the governing equation for fluid flow.

Steady state analysis used to develop the adaptive mesh was carried out using an RNG K- $\varepsilon$ turbulence model by [9] because of its superior responsiveness to the effect of streamline curvature, vortices and rotations.

\section{Methodology}

\section{A. Case Study}

The High-rise building used for the analysis was adopted in [10]. This building was assumed to be situated in Lagos state, Nigeria. The shape and dimension were modified to suit the analysis. It is a $62 \mathrm{~m} \times 30.5 \mathrm{~m} \times 47.8 \mathrm{~m}, 15$ - story typical office building. A $1.22 \mathrm{~m}$ parapet was provided above the last floor making total height of the building equal to $48.8 \mathrm{~m}$. The structural system contained reinforced concrete rigid frames in both directions as shown in Fig. 3. The floor slabs were assumed to provide diaphragm action. 


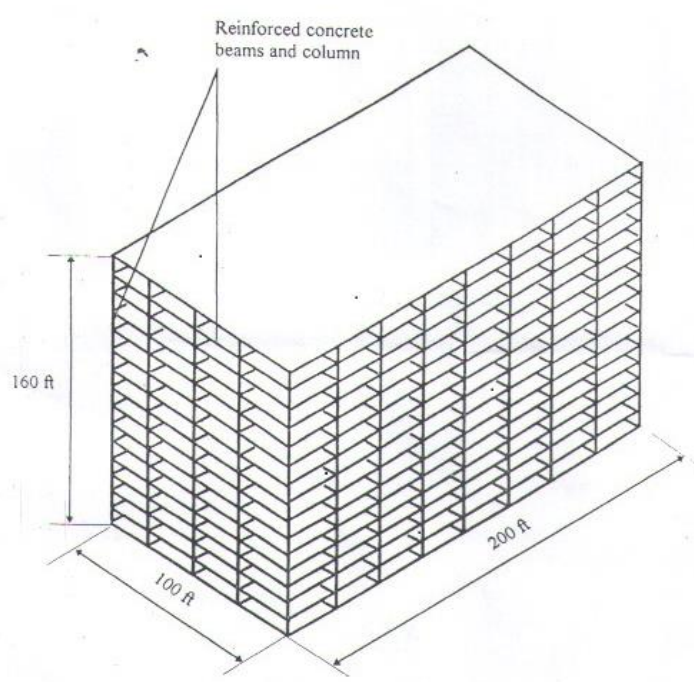

Fig. 3. Structural system of the $48.8 \mathrm{~m}$ tall building

\section{B. Area of The Study}

Wind speed data of Ikeja, Lagos state, Nigeria was used with reference to the wind speed map of Nigeria determined from 40 years of measurement at $10 \mathrm{~m}$ height.

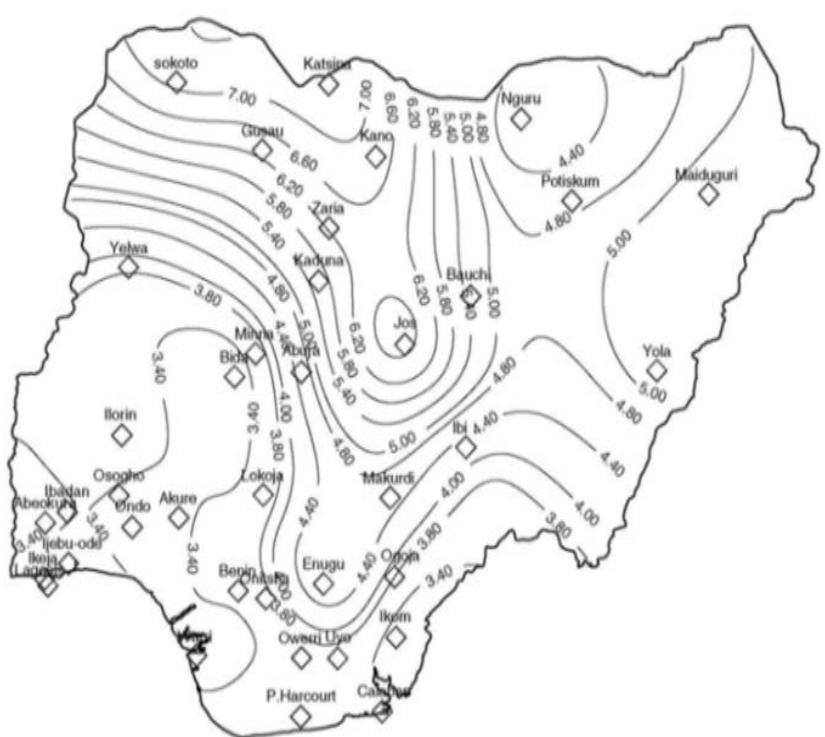

Fig. 4. Nigerian wind map in $\mathrm{m} / \mathrm{s}$ determined from 40 years' measurements at $10 \mathrm{~m}$ height, obtained from Nigerian metrological department, oshodi, lagos state, Nigeria (NIMET) (Source: pubs.sciepub.com/ajee/4/1/1/).

\section{Analytical Procedure}

From the wind speed map above, it can be deduced that Lagos State (Ikeja) has a wind speed of $3.40 \mathrm{~m} / \mathrm{s}$ measured from a 10-meter reference height. Using the logarithmic wind profile equation, wind speed at subsequent height for the high-rise building can be calculated with results, as follows:

\begin{tabular}{ll} 
TABLE I: WIND SPEED AS PER LOGARITHMIC PROFILE LAW \\
\hline \hline STOREY HEIGHT(M) & U(M/S) \\
\hline $15^{\text {th }}$ floor(48.8) & 4.938 \\
$14^{\text {th }}$ floor(44.8) & 4.859 \\
$13^{\text {th }}$ floor(40.95) & 4.768 \\
$12^{\text {th }}$ floor(37.8) & 4.691 \\
$11^{\text {th }}$ floor(34.7) & 4.606 \\
$10^{\text {th }}$ floor(31.5) & 4.514 \\
$9^{\text {th }}$ floor(28.35) & 4.412 \\
\hline \hline
\end{tabular}

\begin{tabular}{ll}
\hline \hline $8^{\text {th }}$ floor(25.2) & 4.297 \\
$7^{\text {th }}$ floor(22.05) & 4.168 \\
$6^{\text {th }}$ floor(18.9) & 4.018 \\
$5^{\text {th }}$ floor(15.75) & 3.841 \\
$4^{\text {th }}$ floor(12.6) & 3.625 \\
$3^{\text {rd }}$ floor(9.45) & 3.346 \\
$2^{\text {nd }}$ floor(6.30) & 2.953 \\
$1^{\text {st }}$ floor(3.150) & 2.280 \\
\hline \hline
\end{tabular}

Now, the Design wind speed can be calculated as

$$
\begin{aligned}
& V_{\mathrm{s}}=V_{\mathrm{b}} \times S_{\mathrm{a}} \times S_{\mathrm{d}} \times S_{\mathrm{s}} \times S_{\mathrm{p}} \\
& S_{\mathrm{a}}=1+0.001 \Delta_{S}
\end{aligned}
$$

To determine the standard effective wind speed

$$
V_{\mathrm{e}}=V_{\mathrm{s}} \cdot S_{\mathrm{b}}
$$

Calculate the dynamic pressure

$$
q_{\mathrm{s}}=0.613 V_{\mathrm{e}^{2}}^{2}
$$

To calculate the external wind pressure on the windward wall, leeward and sidewall of the tall building.

$$
P_{\mathrm{e}}=q_{\mathrm{b}} \cdot C_{\mathrm{a}} \cdot C_{\mathrm{pe}}
$$

Where $\boldsymbol{V}_{\mathbf{s}}$ is the site wind speed, $\boldsymbol{V}_{\mathbf{b}}$ is the basic wind speed, $\boldsymbol{V}_{\mathbf{e}}$ is standard effective wind speed, $\boldsymbol{S}_{\mathbf{a}}$ is an altitude factor, $\Delta_{S}$ is the site altitude in meters, $\boldsymbol{S}_{\mathrm{dis}}$ a direction factor, $S_{\mathrm{s}}$ is a seasonal factor, $\boldsymbol{S}_{\mathrm{p}}$ is a probability factor, $\boldsymbol{S}_{\mathrm{b}}$ is the roughness factor, $\boldsymbol{q}_{\mathrm{s}}$ is the dynamic pressure, $\mathbf{P}_{\mathbf{e}}$ stands for the wind pressure, $\boldsymbol{C}_{\mathbf{a}}$ is the size effect factor for external pressure, $\boldsymbol{C}_{\mathrm{pe}}$ is the external pressure coefficient for the building surface.

\section{RESULTS}

It is very necessary to understand flow pattern around buildings in order to validate a model result in CFD simulation. The CFD simulation was able to display regions of FLOW SEPARATION as well as WAKE of the high-rise building. When wind flows across a bluff body (Rectangular high-rise building) in contrast to a streamlined body, the flow separates as seen in the diagram below. Flows tend to separate when it comes across a positive pressure gradient (adverse pressure gradient). This pressure gradient is strongly felt near the windward wall of the high-rise building than it is at the free stream.

As wind blows on a high-rise building, it causes a shear stress (wall shear stress) to develop on the face of the building perpendicular to the upstream flow. The wall shear stress will tend to retard the flow but a continuous retardation of the flow brings the wall shear stress to a value of zero. At this point, the flow is seen to separate and as the shear stress reduces further to negative, the flow reverses and a region of recirculation flow develops as can be seen in Fig. 5 and 6. 


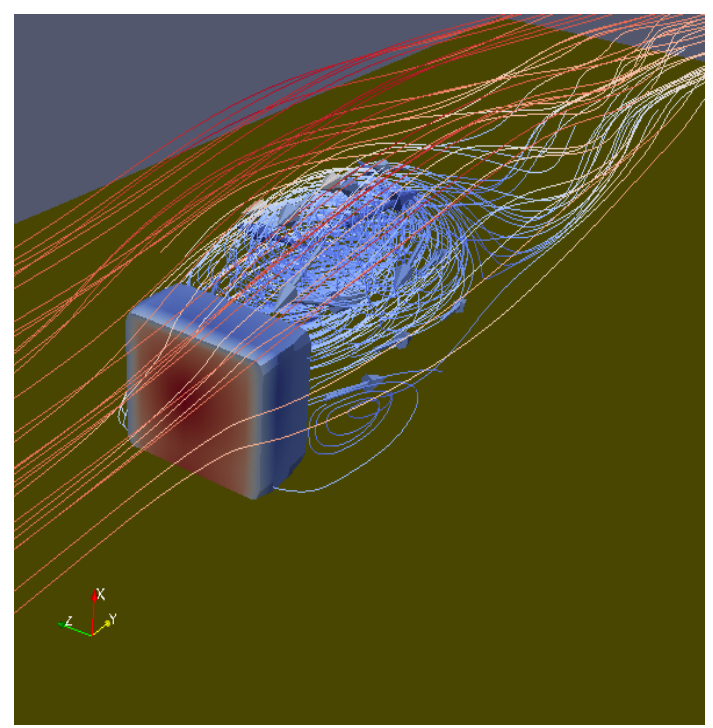

Fig. 5. Pressure load and flow visualization for CFD model

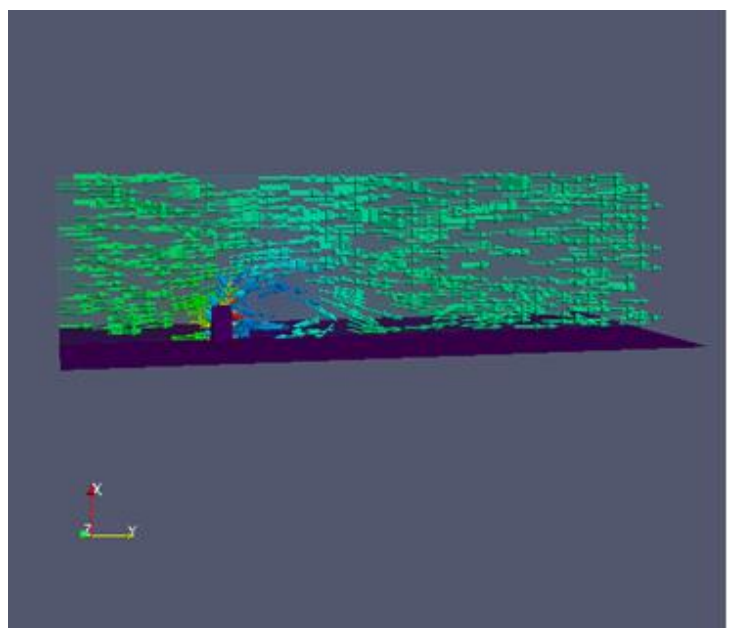

Fig. 6. Symmetrical view of flow pattern on the high-rise building using glyphs

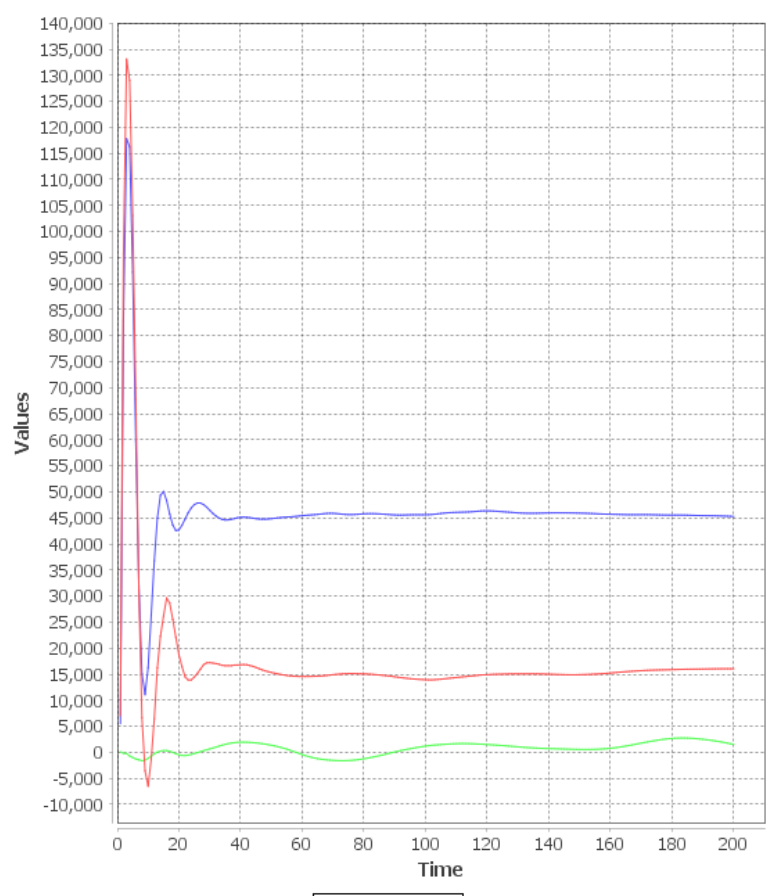

Fig. 7. Load components for the high-rise building case study as per CFD analysis
TABLE II: PRESSURE DISTRIBUTION AS PER CFD ANALYSIS

\begin{tabular}{lllll}
\hline \hline Floor & $\begin{array}{l}\text { Height } \\
(\mathbf{m})\end{array}$ & $\begin{array}{l}\text { Pe windward } \\
(\mathbf{p a})\end{array}$ & $\begin{array}{l}\text { Pe leeward } \\
(\mathbf{P a})\end{array}$ & $\begin{array}{l}\text { Pe sidewall } \\
(\mathbf{P a})\end{array}$ \\
\hline $1^{\text {st }}$ & 3.150 & 9.77978 & -6.63205 & -7.57455 \\
$2^{\text {nd }}$ & 6.300 & 9.76119 & -6.61462 & -7.6775 \\
$3^{\text {rd }}$ & 9.450 & 10.1147 & -6.55717 & -7.8549 \\
$4^{\text {th }}$ & 12.60 & 10.6239 & -6.48968 & -7.99807 \\
$5^{\text {th }}$ & 15.70 & 11.119 & -6.427 & -8.09567 \\
$6^{\text {th }}$ & 18.70 & 11.6761 & -6.39705 & -8.10458 \\
$7^{\text {th }}$ & 22.05 & 12.0817 & -6.39669 & -8.19952 \\
$8^{\text {th }}$ & 25.20 & 12.2872 & -6.42471 & -8.35285 \\
$9^{\text {th }}$ & 28.35 & 12.1847 & -6.47618 & -8.47125 \\
$10^{\text {th }}$ & 31.50 & 11.608 & -6.56644 & -8.50135 \\
$11^{\text {th }}$ & 34.65 & 10.6887 & -6.66159 & -8.43112 \\
$12^{\text {th }}$ & 37.80 & 9.729 & -6.76585 & -8.37891 \\
$13^{\text {th }}$ & 40.95 & 8.63142 & -6.87111 & -8.21384 \\
$14^{\text {th }}$ & 44.80 & 6.63546 & -7.04327 & -8.00827 \\
$15^{\text {th }}$ & 48.77 & -2.42966 & -7.85219 & -7.15603 \\
\hline \hline & & & & \\
\hline
\end{tabular}

TABLE III: WIND PRESSURE DISTRIBUTION AS PER [5]

\begin{tabular}{lllll}
\hline \hline Floor(m) & $\begin{array}{l}\text { Pe } \\
\text { windward } \\
(\mathbf{p a})\end{array}$ & $\begin{array}{l}\text { Pe } \\
\text { leeward } \\
(\mathbf{P a})\end{array}$ & $\begin{array}{l}\text { Pe } \\
\text { sidewall } \\
\mathbf{A}(\mathbf{P a})\end{array}$ & $\begin{array}{l}\text { Pe } \\
\text { sidewall } \\
\mathbf{B}(\mathbf{P a})\end{array}$ \\
\hline $15^{\text {th }}$ floor(48.8) & 39.406 & -32.362 & -85.120 & -52.382 \\
$14^{\text {th }}$ floor(44.8) & 38.682 & -31.367 & -82.598 & -50.829 \\
$13^{\text {th }}$ floor(40.9) & 37.904 & -30.249 & -79.743 & -49.073 \\
$12^{\text {th }}$ floor(37.8) & 37.214 & -29.306 & -77.345 & -47.596 \\
$11^{\text {th }}$ floor(34.7) & 36.481 & -28.295 & -74.759 & -46.005 \\
$10^{\text {th }}$ floor(31.5) & 35.675 & -27.202 & -71.950 & -44.277 \\
$9^{\text {th }}$ floor(28.3) & 34.541 & -26.013 & -68.885 & -42.391 \\
$8^{\text {th }}$ floor(25.2) & 33.128 & -24.712 & -65.513 & -40.315 \\
$7^{\text {th }}$ floor(22.0) & 31.465 & -23.272 & -61.762 & -38.007 \\
$6^{\text {th }}$ floor(18.9) & 29.548 & -21.657 & -57.540 & -35.409 \\
$5^{\text {th }}$ floor(15.7) & 27.213 & -19.816 & -52.706 & -32.435 \\
$4^{\text {th }}$ floor(12.6) & 24.290 & -17.666 & -47.040 & -28.948 \\
$3^{\text {rd }}$ floor(9.45) & 20.352 & -15.068 & -40.168 & -24.719 \\
$2^{\text {nd }}$ floor(6.30) & 16.268 & -11.749 & -31.135 & -19.293 \\
$1^{\text {st }}$ floor(3.15) & 12.673 & -7.0041 & -18.982 & -11.681 \\
\hline \hline
\end{tabular}

TABLE IV: PRESSURE COEFFICIENT AS PER CFD ANALYSIS

\begin{tabular}{llll}
\hline \hline Floor & $\begin{array}{l}\text { Windward } \\
\left(\boldsymbol{C}_{\boldsymbol{P}}\right)\end{array}$ & $\begin{array}{l}\text { Leeward } \\
\left(\boldsymbol{C}_{\boldsymbol{P}}\right)\end{array}$ & $\begin{array}{l}\text { Sidewall } \\
\left(\boldsymbol{C}_{\boldsymbol{P}}\right)\end{array}$ \\
\hline $15^{\text {th }}$ floor(48.8) & 0.654871 & -0.52575 & -0.47914 \\
$14^{\text {th }}$ floor(44.8) & 0.653627 & -0.47159 & -0.5362 \\
$13^{\text {th }}$ floor(40.95) & 0.677298 & -0.46122 & -0.54997 \\
$12^{\text {th }}$ floor(37.8) & 0.711395 & -0.45302 & -0.56102 \\
$11^{\text {th }}$ floor(34.7) & 0.744548 & -0.44604 & -0.56452 \\
$10^{\text {th }}$ floor(31.5) & 0.781852 & -0.43966 & -0.56922 \\
$9^{\text {th }}$ floor(28.35) & 0.809012 & -0.43362 & -0.5672 \\
$8^{\text {th }}$ floor(25.2) & 0.822773 & -0.43018 & -0.55928 \\
$7^{\text {th }}$ floor(22.05) & 0.815909 & -0.4283 & -0.54901 \\
$6^{\text {th }}$ floor(18.9) & 0.777292 & -0.42832 & -0.54265 \\
$5^{\text {th }}$ floor(15.75) & 0.715734 & -0.43033 & -0.54206 \\
$4^{\text {th }}$ floor(12.6) & 0.651471 & -0.43453 & -0.53552 \\
$3^{\text {rd }}$ floor(9.45) & 0.577975 & -0.43904 & -0.52594 \\
$2^{\text {nd }}$ floor(6.30) & 0.444322 & -0.44289 & -0.51406 \\
$1^{\text {st }}$ floor(3.150) & -0.16269 & -0.44406 & -0.50716 \\
\hline \hline
\end{tabular}


TABLE V: VELOCITY COMPONENTS AS PER CFD ANALYSIS

\begin{tabular}{lllll}
\hline \hline Floor(TC3) & Height(m) & $\mathbf{U}_{\mathbf{X}}$ & $\mathbf{U}_{\mathbf{Y}}$ & $\mathbf{U}_{\mathbf{Z}}$ \\
\hline $1^{\text {st }}$ & 3.150 & -0.59952 & 0.582345 & -0.17398 \\
$2^{\text {nd }}$ & 6.300 & -0.73842 & 1.03712 & -0.16474 \\
$3^{\text {rd }}$ & 9.450 & -0.73902 & 1.38129 & -0.16512 \\
$4^{\text {th }}$ & 12.60 & -0.63602 & 1.68535 & -0.16749 \\
$5^{\text {th }}$ & 15.70 & -0.42208 & 1.93389 & -0.16688 \\
$6^{\text {th }}$ & 18.70 & -0.20615 & 2.08387 & -0.16185 \\
$7^{\text {th }}$ & 22.05 & 0.038058 & 2.20521 & -0.15265 \\
$8^{\text {th }}$ & 25.20 & 0.236222 & 2.27589 & -0.14305 \\
$9^{\text {th }}$ & 28.35 & 0.450294 & 2.27255 & -0.14062 \\
$10^{\text {th }}$ & 31.50 & 0.799875 & 2.19495 & -0.13903 \\
$11^{\text {th }}$ & 34.65 & 1.19959 & 2.13108 & -0.12419 \\
$12^{\text {th }}$ & 37.80 & 1.50684 & 2.1050 & -0.10558 \\
$13^{\text {th }}$ & 40.95 & 1.97283 & 2.09299 & -0.08162 \\
$14^{\text {th }}$ & 44.80 & 2.42099 & 2.2018 & -0.05831 \\
$15^{\text {th }}$ & 48.77 & 2.56335 & 2.13023 & -0.02722 \\
\hline \hline
\end{tabular}

\section{CFD PREDICTION VS CODE ESTIMATES}

Wind pressures obtained in the CFD analysis were compared to the wind pressure prediction given in [5]. From the result obtained, the authors observed that in [5], positive wind pressure tends to increase with increase in height (see Table II). As shown in Table II, the greatest windward pressure was recorded at $48.768 \mathrm{~m}$ top of the high-rise building with a value of $39.406 \mathrm{~Pa}$ while the lower part of the high-rise building $(3.150 \mathrm{~m})$ recorded the lowest positive pressure at a value of $12.63 \mathrm{~Pa}$.

Wind flow field is a turbulent boundary layer rather than smooth and uniform boundary layer. [5], assumes wind flow to exist in a laminar boundary layer (flows in parallel layers without lateral mixing). This assumption is what accounts for the corresponding increase of wind pressure with height as observed in [5]. whereas, CFD analyzes wind around building to exist in a turbulent boundary layer characterized by chaotic changes in pressure and flow velocity as shown in Table I. In Table I, the highest windward pressure was recorded in the $8^{\text {th }}$ floor with a value of $12.287 \mathrm{~Pa}$ while the $14^{\text {th }}$ floor recorded a positive pressure value of a $6.63546 \mathrm{~Pa}$.

More so, wind around building is a three dimensional phenomenon rather than a two dimensional phenomenon [11]. Reference [5], addresses only the component of the wind load that is parallel to the direction of the approaching mean wind. This is contrary to CFD analysis which addresses the mean along wind loading $\left(F_{\mathrm{x}}\right)$, across wind loading $\left(\mathrm{F}_{\mathrm{Y}}\right)$ and torsional loading $\left(\mathrm{F}_{\mathrm{Z}}\right)$ (Fig. 7). wind has been discovered to produce torsional loads and cross wind loads perpendicular to the approaching mean wind that act simultaneously with the along wind loads to produce complex load combinations which can cause structural failures due to resonances created as a result of intense harmonic cross wind excitations (vortex shedding). Under certain conditions, the frequency of the shedding can coincide with the natural frequency of vibration of the structure which causes resonances to develop as a result of excessive dynamic responses.

Pressure and shape coefficients for building cross section other than rectangular are not sufficiently documented to be used in [5]. CFD technique on the other hand can provide flow properties around buildings with complex geometrical shapes at any point simultaneously by modeling the actual surrounding in full scale.

According to the results obtained from the analysis, the maximum pressure coefficient on the windward, leeward and sidewall of the high-rise building using CFD analysis are $0.82,-0.42$ and -0.50 respectively. Whereas [5], prescribed the pressure coefficient of $0.85,-0.5$, and -1.3 as maximum $c_{p}$ value at the windward, leeward and sidewall of the high-rise building respectively.

Lastly, when comparing the code analytical methods [5] to the CFD analysis, the results showed that the CFD predictions were typically lower than that predicted when using the code analytical method [5] (See Table I and II). Both the CFD result and code calculations assume the worst-case dominant opening to provide the upper range values shown. This however, is a severe design requirement where CFD predictions can result to greater economy in the structural framing.

\section{CONCLUSIONS}

The wind pressures at different levels of the building given by CFD simulation for the 48.768 metres high-rise building were compared to the predictions given by the British Standard in [5]. Also, the limitations of the [5] to CFD analysis were discussed. The authors also noted that with strict compliance to the available literatures [1], [2] and [3] of best practice guideline recommendations on CFD for Wind around Building Analysis, CFD can serve as a powerful tool in predicting with reasonable accuracy wind phenomenon around Buildings.

\section{REFERENCES}

[1]. J.Franke, A.Hellsten, H.Schlunzen, B.Carrissimo, (2007) "best practice guidelines for the CFD simulation of flows $\mathrm{n}$ urban environment". COST 732: quality assurance and improvement of micro scale meteorological models. Cost office Brussel, ISBN 3-00018312-4.

[2]. J.Franke,C.Hirsch,A.Jensen,H.Krus,M.Schatzmann,P.Westbury,S.Mil es,J.Wisse,N.Wright,(2004) "Recommendations on the use of CFD in wind engineering", COST ActionC14:Impact of Wind and storm on city life and Built Environment,von Karman Institute for Fluid Dynamics.

[3]. Y.Tominaga,A.Mochida,R.Yoshie,H.Kataoka,T.Nozu,M.Yoshikara,T Shirasawa,(2008). Aij guidelines around buildings.Journal of wind engineering and industrial Aerodynamics[online]96(10-11),17491761.ISSN $0167-$ 6105,Available:http://dx.doi.org/10.1016/j.jweia.2008.02.058

[4]. B.Blocken, T.Stathopoulos, J.Carmeliet, CFD simulation of the atmospheric boundary layer: wall function problems.atmos.enviro.[online].41(2), 228-252.

[5]. BS6399-2:1997.Loading for buildings-part 2: code of practice for wind loads BSI

[6]. P.Richards \& R.Hosey, Appropriate boundary conditions for computational wind engineering model usng the K-e model. J.wind eng.ind.aerod.[online].46-47,145-153.

[7]. A.Parente, C.Bonocci. "On the RANS simulation of neutral ABL flow", the fifth symposium on Computation Wind Engineering (2010).

[8]. T.Cebecci, P.Bradshaw. Momentum Transfer in Boundary Layer; New York. Hemisphere Publishing Corporation,(1977).

[9]. V.Yakhot,S.Orszag,S.Thangam,T.Gatski,C.Speziale,(1992) Development of turbulence model for shear flows by a double expansion technique. physics of fluids.[online].4(7),pp1510-1520.

[10]. C.Okafor, K.Okolie, C.Mbanusi, C.Okafor (2017) Analysis of wind effect on High-rise Building for different terrain category. European journal of Engineering Research and Science [online] 2(12), PP 2330(2017).

[11]. D.Boggs,A.Lepage(2016). Wind Tunnel Methods.SP-240(CD) 
Performance-Based Design of Concrete Buildings for Wind Loads. Special Publication Sponsored by ACI Committee 375, American Concrete Institute, Farmington Hills, Michigan, PP.125-142.

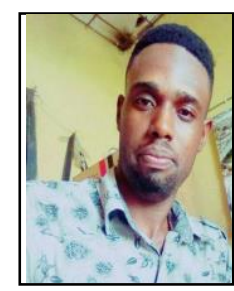

Okafor Chinedum vincent was born in Nigeria. $\mathrm{He}$ obtained B.Sc in Building from Nnamdi Azikiwe University Nigeria in 2012. He is currently doing his M.Sc in Construction Technology in the same institution. His field of interest includes Computational Fluid Dynamics and Structural Design/Analysis. $\mathrm{He}$ has published a number of publications on different peer reviewed international research journals.

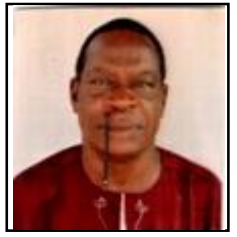

Dr. Ogunoh Peter holds a Bachelor of science Degree in Tech Ed.Building option,Post Graduate Diploma,Masters of Science(MSc) and Doctor of Philosopher Degree $(\mathrm{PhD})$ in construction management.His research interest lies in development of Building maintenance management and Built Asset management system through research and development. Currently,he is a lecturer in the Department of Building, Nnamdi Azikiwe University Awka, Nigeria.

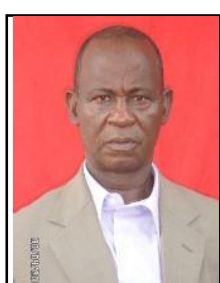

Dr. John Ezeokonkwo graduated from the university of Washington Seattle, USA(Building Construction in 1980) and Seattle University also in USA(Msc in Highway/Transportation Engineering in 1982). He obtained his $\mathrm{PhD}$ in construction management from Nnamdi Azikiwe University Awka, Nigeria. He has published papers and articles in learned Journals, most of which are in Construction Technology and materials management. His area of interest is Concrete Technology, Construction and Materials management.

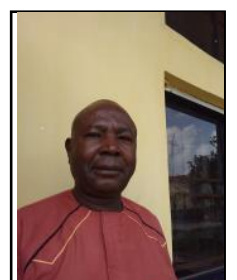

Obodoh Dominic Anosike hails from Eke in Udi Local Government Area of Enugu State,Nigeria.He had his B.Sc in Building from Anambra State University of Technology Enugu,now Enugu State University of Science and TechnologyEnugu. He obtained his M.Eng in Civil Engineering (Structural Engineering) from University of Nigeria Nsukka and is currently running a $\mathrm{PhD}$ in Project Management at the Federal University of Technology Owerri,Nigeria. Obodoh D.A is a lecturer in Building Department at the Nnamdi Azikiwe University Awka Nigeria and is married with four lovely children. 